\title{
EFEK PELATIHAN PADA PENINGKATAN KEMAMPUAN DESAIN GRAFIS, SABLON, DAN PERCETAKAN
}

\author{
Nova Rini ${ }^{1}$, Ahmad Darda ${ }^{2}$, Budiman Abdulah ${ }^{3}$, Wenty Febrianti ${ }^{4}$, Pujihastuti \\ Dwi Julianti ${ }^{5}$
}

1,2,3,4,5 STIE Muhammadiyah Jakarta, nvrin207@yahoo.com

\begin{abstract}
ABSTRAK
Tujuan dari penelitian ini adalah untuk mengetahui kemampuan desain grafis, sablon dan percetakan kepada para pemuda dan pemudi RW 04 Kelurahan Pasar Manggis Kecamatan Setiabudi melalui workshop dan pelatihan desain grafis, sablon dan percetakan yang dilakukan dilingkuangan RW 04. Metode penelitian yang digunakan dalam penelitian ini adalah metode survei dengan menggunakan pendekatan deskriptif analisis melalui penyebaran kuesioner terhadap peserta workshop dan pelatihan desain grafis, sablon, dan percetakan, dimana subjek penelitan dalam penelitian ini adalah pemuda dan pemudi RW 04 Kelurahan Manggarai, Kecamtan Setiabudi Jakarta Selatan, dengan menggunakan analisa data melalui uji beda paired sample test. Hasil dari penelitian ini menunjukan bahwa ada pengaruh nya pelatihan desain grafis, sablon dan percetakan yang dilakukan terhadap peningkatan kemampuan para peserta pelatihan, meskipun tidak terlalu signifikan.
\end{abstract}

Kata kunci : Desain Grafis, Sablon, Percetakan, Pelatihan, dan kemampuan

\begin{abstract}
The purpose of this study was to determine the ability of graphic design, screen printing and printing to young people in $R W$ 04, Pasar Manggis Village, Setiabudi District through workshops and training in graphic design, screen printing and printing conducted in $R W 04$ environment. The research method used in this study is The survey method uses a descriptive analysis approach through distributing questionnaires to workshop participants and training in graphic design, screen printing, and printing, where the research subjects in this study are youths and girls in RW 04 Manggarai Village, Setiabudi District, South Jakarta, using data analysis through different tests. paired sample test. The results of this study indicate that there is an influence on the training of graphic design, screen printing and printing carried out on increasing the abilities of the training participants, although not too significant.
\end{abstract}

Keywords: graphic design, screen printing, printing, training, and ability

Naskah diterima : 21-07-2020, Naskah dipublikasikan : 30-09-2020

http://ejournal.stiemj.ac.id/index.php/ekobis 


\section{PENDAHULUAN}

Pemuda memiliki peran yang sangat penting bagi kemajuan suatu bangsa. Indonesia bisa merdeka pada tahun 1945 diawali dengan pergerakan yang dilakukan oleh para pemuda Indonesia. Begitu pentingnya peran pemuda dalam kemerdekaan suatu bangsa, maka pemuda juga memiliki peran dalam meningkatkan kesejahteraan suatu bangsa khususnya di Indonesia. Prajasurya (2009) menyatakan bahwa masalah pengangguran mengakibatkan pemuda belum berperan penuh dalam pembangunan. Jumlah pencari kerja yang lebih banyak daripada jumlah peluang kerja menyebabkan timbulnya pengangguran. Penyebab pengangguran juga disebabkan karena banyaknya pemuda yang putus sekolah atau yang sudah lulus namun tidak melanjutkan ke jenjang pendidikan lebih tinggi, sehingga tenaga kerja dari pemuda tersebut tidak terserap oleh dunia kerja atau berwirausaha mandiri. Pemberdayaan pemuda dalam kemandirian ekonomi sebagai solusi untuk mengatasi masalah pengangguran. (Andriyani, 2013). Upaya Pemerintah dalam mengatasi pengangguran dari kalangan pemuda adalah dengan membuat Undang-Undang Nomor 40 Tahun 2009 tentang Kepemudaaan undangundang tersebut menyatakan bahwa program Kewirausahaan Pemuda untuk mengatasi pengangguran terdiridari 2 (dua) tahapan. Pertama, Pelatihan Kewirausahaan Pemuda adalah pelatihan bagi pemuda yang belum memiliki usaha dan akan mendirikan usaha kecil. Kedua, Bimbingan Teknis Wirausaha Muda adalah bimbingan bagi wirausaha dalam mengelola, mengembangkan,dan melembagakan usahanya. Seperti yang terjadi di wilayah DKI Jakarta khususnya Kelurahan Pasar Manggis Jakarta Selatan di lingkungan RW 04 masih banyak masyarakat nya yang menganggur dan rata - rata usia pengannguran adalah berusia 25 tahun sampai dengan 30 tahun artinya lebih banyak pemuda - pemudi yang mengalami pengangguran. Sehingga program kewirausahaan mengenai pelatihan bagi pemuda dan pemudi perlu dilaksanakan, untuk menurunkan angka penganguran dikalangan pemuda dan pemudi.

Desain grafis, sablon dan percetakan merupakan salah satu bentuk usaha yang menjanjikan yang dapat memberikan peluang dan keuntungan bagi para pemuda dan pemudi dalam mengembangkan kreatifitas mereka di dunia desain, sehingga dapat menciptakan lapangan kerja baru dikalangan pemuda-pemudi lingkungan RW 04 Kelurahan Pasar Manggis Kecamatan Setiabudi, Jakarta Selatan, yang mana di RW 04 Kelurahan Pasar Manggis belum ada usaha sejenis mengenai desain grafis, sablon dan percetakan, serta adanya situasi yang mendukung karena lokasi di sekitar RW 04 adalah perkantoran, yang mana perkantoran lebih banyak memiliki kebutuhan yang terkait dengan desain grafis, sablon dan percetakan. Berdasarkan permasalahan diatas, oleh karena itu pelatihan kewirausahaan desain grafis, sablon dan percetakan dikalangan pemuda-pemudi RW 04 Kelurahan Pasar Manggis perlu dilakukan dalam upaya meningkatkan kemampuan desain grafis, sablon dan percetakan. 


\section{KAJIAN LITERATUR}

\section{DESAIN GRAFIS, SABLON, DAN PERCETAKAN}

Desain grafis adalah suatu media untuk menyampaikan informasi melalui bahasa komunikasi visual dalam wujud dwimatra ataupun trimatra yang melibatkan kaidahkaidah estetik. (Dewojati, 2009:175).

Widya dan Darmawan (2016:9) mendefinisikan Desain Grafis sebagai sebuah "aplikasi dari keterampilan seni dan komunikasi untuk kebutuhan bisnis dan industri". Aplikasi tersebut digunakan dalam periklanan dan penjualan produk. Selain untuk periklanan dan penjualan produk, aplikasi-aplikasi tersebut dapat menciptakan identitas visual untuk berbagai institusi.

Luzar (2010:779) menjelaskan pengertian Cetak Sablon. Menurut Luzar (2010:779), cetak sablon tersebut merupakan sebuah kegiatan mencetak dengan alat dasar yang digunakan adalah layar saringan (screen) denngan tingkat kerapatan serat tertentu. Tahap berikutnya, screen tersebut diberi sebuah model cetakan atau disebut dengan mal. Model ini berasal dari negative desain yang sudah dibuat terlebih dahulu. Kemudian, tahap berikutnya adalah penyinaran (exposure), hal ini dilakukan untuk mengetahui bentukan bagian-bagian yang dapat dilalui atau tidak oleh tinta. Caranya adalah dengan menuangkan tinta di atas screen dan disapu menggunakan alat yang terbuat dari karet atau disebut dengan rakel.

\section{Kategori Desain Grafis}

Widya dan Darmawan (2016:10) menyatakan secara garis besar, desain grafis dibedakan menjadi beberapa kategori sebagai berikut :

1. Printing (percetakan) yang memuat desain buku, majalah, poster, booklet, leaflet, flyer, pamflet, periklanan, dan publikasi lain yang sejenis.

2. Web design (desain untuk halaman web) atau desain interaktif.

3. Film, termasuk TV komersial, animasi, dan multimedia interaktif.

4. Identifikasi (logo), EGD (Environmental Graphic Design) merupakan desain profesional yang mencakup desain industri (iklan, branding, company profile, dan lain-lain).

5. Desain produk, pemaketan, kemasan, merchandise, dan sebagainya.

\section{PELATIHAN}

\section{Pengertian Pelatihan}

Menurut Kaswan (2011) dalam Harahap dan Silvianita (2016:1958) pelatihan merupakan sebuah proses yang dapat meningkatkan pengetahuan dan keterampilan seseorang. Pelatihan ini bisa meliputi adanya perubahan pada sikap sehingga seseorangbisabekerja secara efektif.

Sikula dalam Mangkunegara (2011:44) menerangkan bahwa pelatihan adalah suatu proses pendidikan jangkapendek yang mempergunakan prosedursistematis dan 
terorganisir dimana pegawai nonmanajerial mempelajari pengetahuan danketerampilan teknis dalam tujuan terbatas.

Dessler (2005) dalam Sulaefi (2017:9) menerangkan bahwa pelatihan adalah proses di mana orang-orang mencapai kemampuan tertentu untuk membantu mencapai tujuan organisasi. Pelatihan lebih cenderung berorientasi jangka pendek, pelatihan berpengaruh pada kinerja, dan jika pelatihan yang dilakukan oleh perusahaan berhasil maka kinerja karyawan akan meningkat dengan sendirinya.

\section{Tujuan Pelatihan}

Marwansyah (2012) dalam Khurotin dan Afriyanti (2018:196) mengemukakan bahwa tujuan pelatihan adalah untuk meningkatkan dan mengasah kemampuan individu dalam mengerjakan setiap tugas atau pekerjaan tertentu secara memuaskan. berikut :

Mangkunegara (2013:45) menyatakan bahwa tujuan pelatihan adalah sebagai

1) Meningkatkan produktivitas kerja

2) Meningkatan kualitas kerja

3) Meningkatkan ketetapan perencanaan sumber daya manusia

4) Meningkatkan penghayatan jiwa dan ideology

5) Meningkatkan sikap moral dan semangat kerja

\section{Komponen Pelatihan}

Byars \& Rue dalam Umi dan Nurnida (2018:1125) mengungkapkan pendapat mereka mengenai komponen pelatihan dan pengembangan yang dapat diukur melalui:

1) Pelatihan, yaitu apakah isi program pelatihan relevan dan sejalan dengan kebutuhan pelatihan, dan apakah pelatihan tersebut up to date.

2) Metode Pelatihan, apakah metode pelatihan yang diberikan sesuai untuk subjek itu dan apakah metode pelatihan tersebut sesuai dengan gaya belajar peserta pelatihan.

3) Sikap dan Keterampilan Instruktur, yaitu apakah instruktur mempunyai sikap dan keterampilan penyampaian yang mendorong orang untuk belajar.

4) Lama waktu pelatihan, yaitu berapa lama waktu pemberian materi pokok yang harus dipelajari dan seberapa cepat tempo penyampaian materi tersebut.

5) Fasilitas Pelatihan, yaitu apakah tempat penyelenggaraan pelatihan dapat dikendalikan oleh instruktur, apakah relevan dengan jenis pelatihan, dan apakah makanannya memuaskan.

\section{Jenis-jenis Pelatihan}

Menurut Simamora (2012:278) terdapat lima jenis pelatihan yang dapat diselenggarakan yaitu : 


\section{Pelatihan Keahlian}

Pelatihan keahlian (skils training) merupakan pelatihan yang sering di jumpai dalam organisasi. Program pelatihaannya relatif sederhana, kebutuhan atau kekuragan diidentifikasi rnelalui penilaian yang jeli, kriteria penilalan efekifitas pelatihan juga berdasarkan pada sasaran yang diidentifikasi dalam tahap penilaian.

\section{Pelatihan Ulang}

Pelatihan ulang (retraining) adalah subset pelatihan keahilan. Pelatihan ulang berupaya memberikan kepada para karyawan keahlian-keahlian yang mereka butuhkan untuk menghadapi tuntutan kerja yang berubah-ubah. Seperti tenaga kerja instansi pendidikan yang biasanya bekerja rnenggunakan mesin ketik manual mungkin harus dilatih dengan mesin computer atau akses internet.

\section{Pelatihan Lintas Fungsional}

Pelatihan lintas fungsional (cros fungtional training) melibatkan pelatihan karyawan untuk melakukan aktivitas kerja dalam bidang lainnya selain dan pekerjan yang ditugaskan.

\section{Pelatihan Tim}

Pelatihan tim merupakan bekerjasarna terdiri dari sekelompok Individu untuk menyelesaikan pekerjaan demi tujuan bersama dalam sebuah tim kerja.

\section{Pelatihan Kreatifitas}

Pelatihan kreatifitas(creativitas training) berlandaskan pada asumsi bahwa kreativitas dapat dipelajari. Maksudnya tenaga kerja diberikan peluang untuk mengeluarkan gagasan sebebas mungkin yang berdasar pada penilaian rasional dan biaya.

\section{KEMAMPUAN \\ Pengertian Kemampuan}

Robbins dan Judge (2008) dalam penelitian Endayani, et.al (2015:3) menyatakan bahwa Kemampuan (ability) adalah kapasitas seorang individu untuk melakukan beragam tugas dalam suatu pekerjaan. Kemampuan (ability) menurut Hasibuan (2010:184) menunjukkan potensi seseorang untuk melaksanakan pekerjaan, mungkin kemampuan itu dimanfaatkan atau mungkin tidak dimanfaatkan.

Gibson dalam Trawardani (2015:52) menyatakan bahwa kemampuan menunjukan potensi orang untuk melaksanakan tugas atau pekerjaan. Karyawan yang mempunyai kemampuan berarti mampu untuk menyelesaikan tugas dan tanggungjawabnya sesuai dengan tuntutan yang diberikan oleh perusahaan.

\section{Macam - Macam Kemampuan Kerja}

Robbins dan Judge (2008) dalam penelitian Arini, et.al (2015:3) menyebutkan bahwa kemampuan kerja terdiri dari : 


\section{Kemampuan intelektual}

Kemampuan intelektual adalah Kemampuan yang ada dalam diri individu yang mencakup pada aktivitas penalaran, mental dan pemecahan masalah. Sebagian besar masyarakat menempatkan kecerdasan intelektual pada nilai yang tinggi.

\section{Kemampuan Fisik}

Robbinsmenjelaskan bahwa Kemampuan fisik merupakan kemampuanindividu dalammenyelesaikan pekerjaannya yang berhubungan dengan kekuatan stamina, kecekatan fisik, dan bakat-bakat serupa yang membutuhkan kemampuan fisik seorang individu. Kemampuan fisik ini mengandalkan kekuatan otot atau kekuatan tubuh

\section{Faktor - Faktor Kemampuan}

Handoko dalam Binardi (2013) dalam penelitian Arini, et.al (2015:3) menjelaskan bahwa terdapat faktor-faktor yang menentukan kemampuan kerja seseorang yaitu : 1) Faktor pendidikan formal 2) Faktor pelatihan 3) Faktor pengalaman kerja.

\section{Penilaian Kemampuan Kerja}

Penilaian kemampuan kerja bertujuan agar meningkatkan motivasi dan kemampuan karyawan sehingga kinerja mereka meningkat (Endayani, 2015:3). As'ad (2003) dalam Endayani (2015:3) penilaian kemampuan kerja memiliki tujuan sebagai berikut :

1. Mengukur prestasi kerja (job proficiency), yaitu sejauh mana karyawan bisa sukses dalam pekerjaannya.

2. Melihat seberapa jauh kemajuan dalam latihan kerja

3. Sebagai data yang dipergunakan sebagai bahan pertimbangan apabila ada promosi bagi karyawan yang bersangkutan.

\section{METODE PENELITIAN}

Metode yang digunakan dalam penelitian ini adalah metode survei dengan menggunakan pendekatan deskriptif analisis. Metode survei ini bertujuan memberikan gambaran tentang masing-masing variabel dengan cara menganalisis pengaruh variabel bebas terhadap variabel terikat.

Data yang digunakan dalam penelitian adalah melalui kuesioner dan Library Reasearch. Kuesioner merupakan teknik pengumpulan data yang dilakukan dengan cara memberi seperangkat pernyataan tertulis kepada responden untuk dijawabnya (Sugiyono, 2011:142).

Sedangkan Library Research(Penelitian Kepustakaan) adalah Metode penelitian yang digunakan berdasarkan studi literatur. Dalam hal ini penulis berusaha mencari dan membaca serta mendapatkan sumber-sumber ilmiah yang terdapat dalam buku, jurnal, dan penelitian terdahulu.

\section{Subjek Penelitian}

Subjek penelitian ini adalah para pemuda dan pemudi RW 04 Kelurahan Pasar Manggis, Kecamatan Setiabudi Jakarta Selatan. 


\section{Metode Analisis Data}

Evaluasi tahap pertama dengan melihat dampak workshop terhadap pengetahuan para pemuda dan pemudi RW 04 Kelurahan Pasar Manggis sebelum dan setelah mengikuti workshop manajemen usaha desain grafis, sablon dan percetakan melalui uji beda paired sample test. Sehingga dapat mengetahui perbedaan pengetahuan sebelum dan setelah mengikuti workshop manajemen usaha. Kemudian evaluasi tahap kedua dengan melihat dampak pelatihan terhadap kemampuan para pemuda dan pemudi RW 04 Kelurahan Pasar Manggis sebelum dan setelah mengikuti pelatihan desain grafis, sablon dan percetakan melalui uji beda paired sample test.Sehingga dapat mengetahui perbedaan kemampuan sebelum dan setelah mengikuti pelatihan.

\section{HASIL DAN PEMBAHASAN}

Pada sesi pertama sebelum workshop dimulai, para peserta diberi kuesioner mengenai pemahaman manajemen usaha. Kemudian sebelum acara ditutup peserta kembali diberi kuesioner mengenai pemahaman manajemen usaha. Kuesioner yang diberikan pada saat sebelum dan setelah mengikuti workshop bertujuan untuk mengukur perubahan pengetahuan dan pemahaman peserta workshop dalam melakukan manajemen usaha desain grafis, sablon dan percetakan.

Kemudian pada sesi kedua sebelum pelatihan dimulai, para peserta diberi kuesioner mengenai kemampuan dalam melakukan desain grafis, sablon dan percetakan, kemudian setelah mengikuti pelatihan para peserta diberi kuesioner kembali untuk mengetahui perubahan kemampuan pada saat sebelum dan setelah mengikuti pelatihan.

Evaluasi sesi pertama berdasarkan hasil kuesioner sebelum dan setelah mengikuti workshop mengenai pemahaman desain grafis, sablon dan percetakan adalah sebagai berikut:

Tabel 1. Deskripsi Data Sebelum dan Setelah Workshop Manajemen Usaha

\begin{tabular}{lcc}
\hline \multicolumn{1}{c}{ Pertanyaan } & $\begin{array}{c}\text { Mean } \\
\text { Sebelum }\end{array}$ & $\begin{array}{c}\text { Mean } \\
\text { Setelah }\end{array}$ \\
\hline 1. Apakah anda mengetahui entreprenuership motivation & 3.33 & 3.92 \\
\hline 2. Apakah anda mengetahui manajemen usaha & 3.25 & 4.17 \\
\hline $\begin{array}{l}\text { 3. Apakah anda mengetahui penyusunan rencana bisnis } \\
\text { 4. Apakah anda mengetahui manajemen keuangan }\end{array}$ & 2.67 & 4.17 \\
\hline 5. Apakah anda sudah mengetahui cara menyusun rencana bisnis & 2.25 & 4.17 \\
\hline 6. Apakah anda sudah mengetahui cara memanajemen sebuah usaha & 3.17 & 4.00 \\
\hline 7. Apakah anda sudah mengetahui cara memanajemen keuangan usaha & 3.00 & 4.00 \\
\hline 8. Apakah anda sudah mengetahui konsep motivasi dalam usaha & 2.75 & 3.25 \\
\hline 9. Apakah anda tertarik untuk memanajemen sebuah usaha secara & 3.58 & 4.67 \\
\hline profesional & & 3.92 \\
\hline 10. Apakah anda tertarik untuk membuat rencana bisnis usaha & 3.67 & 4.25 \\
\hline 11. Apakah anda akan tertarik memanajemen keuangan usaha secara & & 4.25 \\
\hline profesional & Apakah anda akan mengelola usaha dengan konsep manajemen usaha & 3.67 \\
\hline 13. Apakah anda akan mengelola usaha dengan konsep rencana bisnis & 3.42 & 4.50 \\
\hline \hline http://ejournal.stiemj.ac.id/index.php/ekobis & & 140 \\
\hline
\end{tabular}




\begin{tabular}{llcccc}
\hline & Pertanyaan & & Mean & Mean \\
& & Sebelum & Setelah \\
\hline $\begin{array}{l}\text { 14. Apakah anda akan mengelola usaha dengan konsep manajemen } \\
\text { keuangan }\end{array}$ & 3.50 & 4.42 \\
\hline Rata- rata & & & $\mathbf{3 . 2 7}$ & $\mathbf{4 . 1 4}$ \\
\hline Sumber : Kuesioner (2019) & & &
\end{tabular}

Tabel 1 diatas menunjukan bahwa rata-rata peserta workshop sebelum mengikuti workshop manajemen usaha desain grafis, sablon dan percetakan masih terlihat raguragu dalam pemahaman tentang manajemen usaha. Hasil ini menunjukan bahwa peserta workshop masih banyak yang belum memahami mengenai manajemen usaha desain grafis, sablon dan percetakan. Hal ini terlihat dari nilai rata-rata skor persepsi peserta mengenai pengetahuan dan pemahaman manajemen usaha desain grafis, sablon, dan percetakan adalah kurang dari 4 . Tabel 1 diatas juga menunjukan bahwa rata-rata peserta setelah mengikuti workshop manajemen usaha desain grafis, sablon dan percetakan mengalami perubahan pengetahuan dan pemahaman hal ini dapat terlihat bahwa skor rata-rata setelah mengikuti workshop adalah 4 dimana skala likert untuk skor 4 menyatakan bahwa pengetahuan dan kemampuan peserta sudah memuaskan. Untuk mengetahui bahwa perbedaan rata-rata skor tersebut signifikan, maka diuji nilai perbedaan tersebut dengan menggunakan software SPSS.

Tabel 2. Hasil Uji Beda Signifikansi

Paired Samples Test

\begin{tabular}{|c|c|c|c|c|c|c|c|c|}
\hline \multirow{4}{*}{$\begin{array}{l}\text { Pair } 1 \text { sebelum - } \\
\text { setelah }\end{array}$} & \multicolumn{5}{|c|}{ Paired Differences } & \multirow[t]{3}{*}{$\mathrm{t}$} & \multirow[t]{3}{*}{ df } & \multirow{3}{*}{$\begin{array}{l}\text { Sig. (2- } \\
\text { tailed) }\end{array}$} \\
\hline & \multirow[t]{2}{*}{ Mean } & \multirow[t]{2}{*}{$\begin{array}{l}\text { Std. } \\
\text { Deviation }\end{array}$} & \multirow[t]{2}{*}{$\begin{array}{l}\text { Std. } \\
\text { Error } \\
\text { Mean }\end{array}$} & \multicolumn{2}{|c|}{$\begin{array}{l}95 \% \text { Confidence } \\
\text { Interval of the } \\
\text { Difference }\end{array}$} & & & \\
\hline & & & & Lower & Upper & & & \\
\hline & -12.167 & 14.978 & 4.324 & -21.683 & -2.650 & -2.814 & 11 & .017 \\
\hline
\end{tabular}

Sumber : Kuesioner (2019)

Pada tabel 2 diatas menunjukan bahwa hasil uji beda menunjukan bahwa tabel output Paired Samples Test diatas diketahui nilai Sig adalah sebesar $0.017<0.05$ sehingga adanya pengaruh yang signifikan pada saat sebelum dilakukan workshop dan sesudah workshop dilakukan.

Kemudian untuk evaluasi tahap kedua berdasarkan hasil kuesioner sebelum dan setelah mengikuti pelatihan desain grafis, sablon dan percetakan adalah sebagai berikut:

Tabel 3. Deskripsi Data Sebelum dan Setelah Pelatihan Desain Grafis, Sablon, Percetakan

\begin{tabular}{llcc}
\hline \multicolumn{1}{c}{ Pertanyaan } & Mean & Mean \\
& & Sebelum & Setelah \\
\hline 1. Apakah anda mengetahui desain grafis & 4.00 & 4.17 \\
\hline 2. Apakah anda mengetahui sablon & 3.83 & 4.33 \\
\hline 3. Apakah anda mengetahui percetakan & 3.83 & 4.17 \\
\hline 4. Apakah anda tertarik untuk mempelajari desain grafis & 4.50 & 4.33 \\
\hline 5. Apakah anda tertarik untuk membuat membuat sablon & 4.67 & 4.17 \\
\hline
\end{tabular}




\begin{tabular}{|c|c|c|}
\hline Pertanyaan & $\begin{array}{c}\text { Mean } \\
\text { Sebelum }\end{array}$ & $\begin{array}{c}\text { Mean } \\
\text { Setelah }\end{array}$ \\
\hline 6. Apakah anda akan tertarik membuat percetakan & 4.00 & 4.17 \\
\hline 7. Apakah anda akan membuka usaha bidang desain grafis & 3.50 & 4.00 \\
\hline 8. Apakah anda akan membuka usaha bidang sablon & 3.67 & 4.50 \\
\hline 9. Apakah anda akan membuka usaha percetakan & 3.67 & 4.00 \\
\hline Rata - rata & 3.96 & 4.20 \\
\hline
\end{tabular}

Sumber : Kuesioner (2019)

Dari hasil tabel 3 diatas menunjukan bahwa rata-rata sebelum mengikuti pelatihan kemampuan para peserta mengenai desain grafis, sablon dan percetakan yaitu sebesar 3.96 dan berdasarkan skala likert menyatakan masih belum memuaskan, kemudian setelah mengikuti pelatihan ada perbedaan mengenai kemampuan para peserta pelatihan desain grafis, sablon dan percetakan yaitu sebesar 4.20, artinya kemampuan para peserta mengalami kenaikan. Untuk mengetahui bahwa perbedaan rata-rata skor tersebut signifikan atau tidak signifikan, maka diuji nilai perbedaan tersebut dengan menggunakan software SPSS sebagai berikut:

Tabel 4. Hasil Uji Beda Signifikansi

Paired Samples Test

\begin{tabular}{|c|c|c|c|c|c|c|c|c|}
\hline & \multirow{2}{*}{\multicolumn{5}{|c|}{ Paired Differences }} & & \multirow{4}{*}{ df } & \multirow{4}{*}{$\begin{array}{l}\text { Sig. (2- } \\
\text { tailed) }\end{array}$} \\
\hline \multirow{4}{*}{$\begin{array}{l}\text { Pair } 1 \text { sebelum } \\
\text { setelah }\end{array}$} & & & & & & \multirow[t]{3}{*}{$\mathrm{t}$} & & \\
\hline & \multirow[t]{2}{*}{ Mean } & \multirow[t]{2}{*}{$\begin{array}{l}\text { Std. } \\
\text { Deviation }\end{array}$} & \multirow[t]{2}{*}{$\begin{array}{l}\text { Std. } \\
\text { Error } \\
\text { Mean }\end{array}$} & \multicolumn{2}{|c|}{$\begin{array}{l}\text { 95\% Confidence } \\
\text { Interval of the } \\
\text { Difference }\end{array}$} & & & \\
\hline & & & & Lower & Upper & & & \\
\hline & -2.167 & 5.382 & 2.197 & -7.815 & 3.481 & -.986 & 5 & .369 \\
\hline
\end{tabular}

Sumber : Kuesioner (2019)

Pada tabel 4 diatas menunjukan bahwa hasil uji beda menunjukan bahwa tabel output Paired Samples Test diatas diketahui nilai Sig adalah sebesar $0.369>0.05$ meskipun secara rata-rata sebelum dan setelah mengikuti pelatihan ada perbedaan kemampuan desain grafis, sablon, percetakan, akan tetapi secara uji signifikan tidak ada pengaruh yang signifikan pada saat sebelum dilakukan pelatihan dan sesudah pelatihan dilakukan.

\section{PENUTUP}

\section{Simpulan}

Kesimpulan yang dihasilkan dari kegiatan workshop manajemen usaha dan pelatihan desain grafis, sablon dan percetakan kepada para pemuda dan pemudi RW 04 Kelurahan Pasar Manggis, Kecamatan Setiabudi, Jakarta Selatan terbukti dapat meningkatkan pengetahuan dan kemampuan para pemuda dan pemudi dalam melakukan praktek desain grafis, sablon dan percetakan. Kegiatan workshop manajemen usaha desain grafis, sablon dan percetakan kepada para pemuda-pemudi RW 04 Kelurahan Pasar Manggis membuat para pemuda dan pemudi di wilayah RW 04 dapat mengetahui rencana bisnis desain grafis, sablon dan percetakan. Sehingga 
menambah ketertarikan dalam membuat dan menjalankan usaha desain grafis, sablon dan percetakan.

\section{Saran}

Sedangkan saran yang dapat diberikan dalam penelitian ini adalah para pemuda dan pemudi di wilayah RW 04 Kelurahan Pasar Manggis Kecamatan Setiabudi perlu mendapatkan pendampingan dalam menjalankan usaha desain grafis, sablon dan percetakan dari pelaku usaha yang sudah eksis terlebih dahulu dibidang desain grafis, sablon dan percetakan.Perlu adanya suatu perkumpulan usaha desain grafis, sablon dan percetakan kepada pemuda dan pemudi RW 04 agar usaha yang dijalankan dapat terus berjalan, sehingga dapat memperkuat modal dan kreatifitas.Perlu adannya workshop dan pelatihan wirausaha lainnya sehingga dapat menggali potensi-potensi lain yang dimiliki oleh para pemuda dan pemudi RW 04 Kelurahan Pasar Manggis sehingga dapat mengembangkan wirausaha lain demi kemajuan lingkungan RW 04 dan sekitarnya.

\section{REFERENSI}

Admin. (2017). Undang-Undang Nomor 40 Tahun 2009Tentang Kepemudaan. https://peraturan.bpk.go.id/Home/Details/38784/uu-no-40-tahun-2009 (Diakses 5 September 2019)

Andriyani, Merry. (2013). "Pemberdayaan Pemuda Melalui Program Kewirausahaan Pemuda". PublikA, Jurnal S-1 Ilmu Administrasi Negara, Vol. 2, No 1, hal 1-5.

Arini, Kiki Rindy., Mochammad Djudi Mukzam., Ika Ruhana. (2015). "Pengaruh Kemampuan Kerja Dan Motivasi Kerja Terhadap Kinerja Karyawan (Studi Pada Karyawan PT. Perkebunan Nusantara X (Pabrik Gula) Djombang Baru)". Jurnal Administrasi Bisnis. Vol.22, No. 1, hal. 1-9

Endayani, Fatmasari., Djamhur Hamid., Mochamad Djudi. "Pengaruh Pelatihan Kerja Terhadap Kemampuan Kerja Dan Kinerja Karyawan PT. BPRS Bumi Rinjani Kepanjen". Jurnal Administrasi Bisnis. Vol. 25, No.1, Hal. 1-7.

Harahap, Riri Ainun Mardiah., Anita Silvianita. (2016). "Pengaruh Pelatihan Terhadap Kinerja Karyawan PT Pos Indonesia (Persero) Regional V Bandung”. eProceeding of Management. Vol. 3, No.2, hal. 1956-1973.

Hasibuan, S.P. Malayu. (2010). Manajemen Sdm. Bumi Aksara. Jakarta

Khurotin, Nurul., Tri Wulida Afrianty. (2018). "Analisis Pelatihan Dan Pengembangan Sumber Daya Manusia Di PT. Beon Intermedia Cabang Malang”. Jurnal Administrasi Bisnis (JAB). Vol. 64, No. 1, Hal. 195-203.

Luzar, Laura Christina. (2010). "Kreasi Cetak Sablon Mudah Dan Berkualitas Tinggi Pada Kaos”. Humanior. Vol.1, No.2, hal. 778-791. 
Mangkunegara, Anwar Prabu. (2011). Manajemen Sumber Daya Manusia Perusahaan. PT Remaja Rosdakarya. Bandung:.

Mangkunegara, Anwar Prabu. (2013). Manajemen Sumber Daya Manusia Perusahaan. PT. Remaja Rosda Karya. Bandung.

Prajasurya. (2009). Semangat Kewirausahaanhttp://bpplsp.go.id/kewirausahaan.html

(Diakses 5 September 2019)

Simamora, Henry . (2012). Manajemen Sumber Daya Manusia. Edisi 1. STIE YKPN Yogyakarta. Yogyakarta.

Sugiyono. (2011). Metode Penelitian Kuantitatif Kualitatif dan R\&D. Edisi ke 13. Alfabeta. Bandung

Sulaefi. (2017). "Pengaruh Pelatihan Dan Pengembangan Terhadap Disiplin Kerja Dan Kinerja Karyawan”. Jurnal manajemen dan kewirausahaan. Vol. 5, No. 1, hal. 8-21.

Trawardani, Isa Bharoka., Arik Prasetya., Yuniadi Mayowan. (2015). "Pengaruh Pelatihan Terhadap Kemampuan Kerja Yang Berdampak Pada Kinerja Karyawan (Studi Pada Karyawan PT Bank Rakyat Indonesia (Pesero) Tbk Cabang Lumajang)". Jurnal Administrasi Bisnis. Vol. 29, No. 1, hal. 51-58.

Umi, Marini Zakiyatul., Ida Nurnida. (2018). "Pengaruh Pelatihan Terhadap Kinerja Karyawan:Studi Pada Pt. Mitra Solusi Telematika (Mst) Jakarta”. e-Proceeding of Management. Vol. 5, No.1, hal. 1123-1129

Widya, Leonardo Adi Dharma., Andreas James Darmawan. (2016).Bahan ajar kursus dan pelatihan desain grafis. Kementerian Pendidikan dan Kebudayaan. Jakarta.

Wulan, Dewojati, R. Kuncoro. (2009). "Desain Grafis Sebagai Media Ungkap Periklanan”. Imaji Jurnal Seni Dan Pendidikan Seni , Vol.7, No. 2, hal : 175 182. 